\title{
Determination of Groundwater Flow Direction in Utagba-Ogbe Kingdom, Nokwa Land Area of Delta State, Nigeria
}

\author{
Oseji Julius Otutu and Ofomola Merrious Oviri \\ Department of Physics, Delta State University, Abraka, Nigeria
}

\begin{abstract}
A study was carried out in Utagba-Ogbe Kingdom, Ndokwa West local government area of Delta state using the Global Positioning System (GPS) and meter tape to determine the groundwater flow pattern of the area. The longitudes, latitudes and elevations of 6 locations evenly distributed within the kingdom were measured and recorded. The depths to the water level in the hand-dug wells were measured directly with the aid of a meter tape. The water elevation contour map of Utagba-Ogbe Kingdom revealed that groundwater flow direction is toward the Eastern part of the kingdom. It is therefore recommended that dumpsites should be sited within the eastern part of the kingdom while boreholes for potable groundwater exploitation could be sited in the North, South and Western regions of the kingdom to minimize groundwater contamination. In the event of pollution groundwater within the Eastern regions of Utagba-Ogbe Kingdom are densely contaminated. Therefore, communities within the North, West and Southern regions of Utagba-Ogbe Kingdom should take steps to ensure that land use activities will not pose a threat on the quality of groundwater. The present study act as a guide for future groundwater exploration, hence the information will be useful to both the government and individuals especially those in water industries in sinking and maintaining boreholes for optimum groundwater exploitation.
\end{abstract}

Key words: Flow direction, dumpsites, static water level, surface elevation, ground water, exploitation

\section{INTRODUCTION}

The study area Utagba-Ogbe Kingdom is within the Sombriero Warri deltaic plain deposit invaded by mangrove and located within latitude $5^{\circ} 66^{\prime} \mathrm{N}$ and $5^{\circ} 75^{\prime} \mathrm{N}$ and longitude $6^{\circ} 40^{\prime} \mathrm{E}$ and $6^{\circ} 45^{\prime} \mathrm{E}$ as shown in Fig. 1. The geology and geomorphology of the NigerDelta have been described by Allen (1965), Akpokodje (1979, 1987), Asseez (1970, 1976), Avbovbo (1970), Oomkens (1974), Burke (1972), Rement (1965), Short and Stauble (1967), Hospers (1965), Etu-Efeotor and Akpokodje (1990), Maron (1969) and Kogbe and Asseez (1970).

When rain falls to the ground, the water does not stop moving. Some of it flows along the surface in streams or lakes, plants use some while some evaporates and returns to the atmosphere others sink into the ground. Imagine putting a glass of water onto a pile of sand. Where does the water go? The water moves into the spaces between the particles of sand.

Groundwater, therefore is that which exist below the earth surface, within saturated layers of sand, gravel and pore-spaces in sedimentary or crystalline rocks while

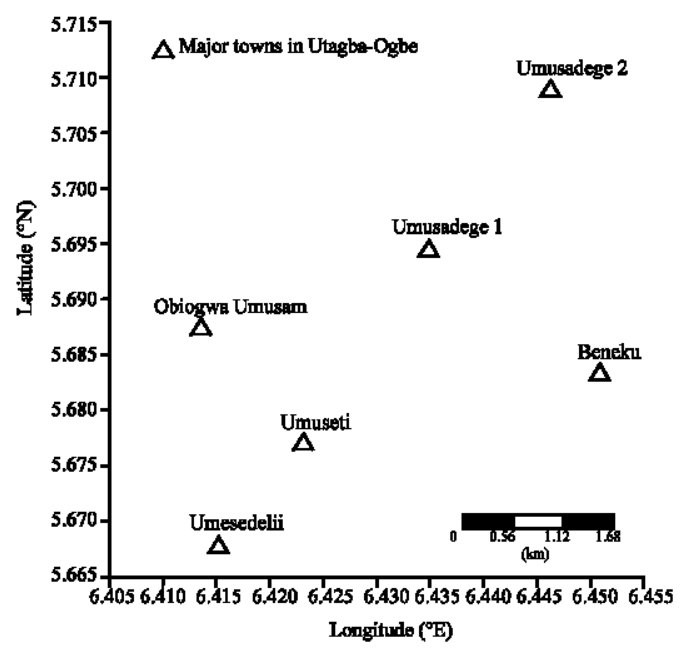

Fig. 1: The base map of Utagba-Ogbe kingdom

freshwater is the water from the zone that is not invaded. (Tyson, 1993). When more rainfall occurs, the solute penetrates the soil deeper and this percolates the water table. During percolation, the water leaches the buried pipes, waste materials from the gas plant, industries, factories and washes down the spilled oil into the soil

Corresponding Author: Oseji Julius Otutu, Department of Physics, Delta State University, Abraka, Nigeria 
thereby becoming part of the flow system immediately it gets to the water table (Oseji et al., 2005; Oyedele, 2001; Wilson, 1990).

The depth to water table can be determined by digging a hole progressively deeper into the ground, the depth at which water begins to seep into the hole indicate that the surrounding material is saturated with water and this mark the height of the local water where there is no surface water (Buddemeier and Schloss, 2000). Groundwater flow is very slow compared to surface water movement. However, groundwater, like surface water, flows downhill in the direction determined by the slope of the water table. Groundwater flow is therefore, from high hydraulic head (high water level) to low hydraulic head (low water level) (Buddemeier and Schloss, 2000).

\section{MATERIALS AND METHODS}

The Global Positioning System (GPS) of type 310 was used to measure the longitude, latitude and surface elevations with respect to the mean sea level at six locations evenly distributed within Utagba-Ogbe kingdom. With the aid of a meter rule, the depths to the water level in the hand dug wells were measured directly and recorded. The static water level of the different locations were obtained by subtracting the elevation with respect to the mean sea level from the depth to the water level in the hand-dug well (Buddemeier and Schloss, 2000). Therefore:

Where:

$$
\mathrm{S}_{\mathrm{wd}}=\mathrm{E}-\mathrm{D}_{\mathrm{wd}}
$$

$D_{\mathrm{w}}=$ Depth from the surface of the earth to the water level in the hand dug wells

$\mathrm{E}=$ Surface elevation with respect to the mean sea level

$\mathrm{S}_{\mathrm{wl}}=$ The static water level otherwise known as the true or uniform water level

The values of the static water levels were contoured using the longitudes and latitude in mapping out the locations within Utagba-Ogbe Kingdom. According to Buddemeier and Schloss (2000), groundwater flows from the highest values of the contour lines to the lowest values in the direction perpendicular to the contour lines.

\section{RESULTS AND DISCUSSION}

Six locations were surveyed within Utagba-Ogbe Kingdom and the values of the static water levels were

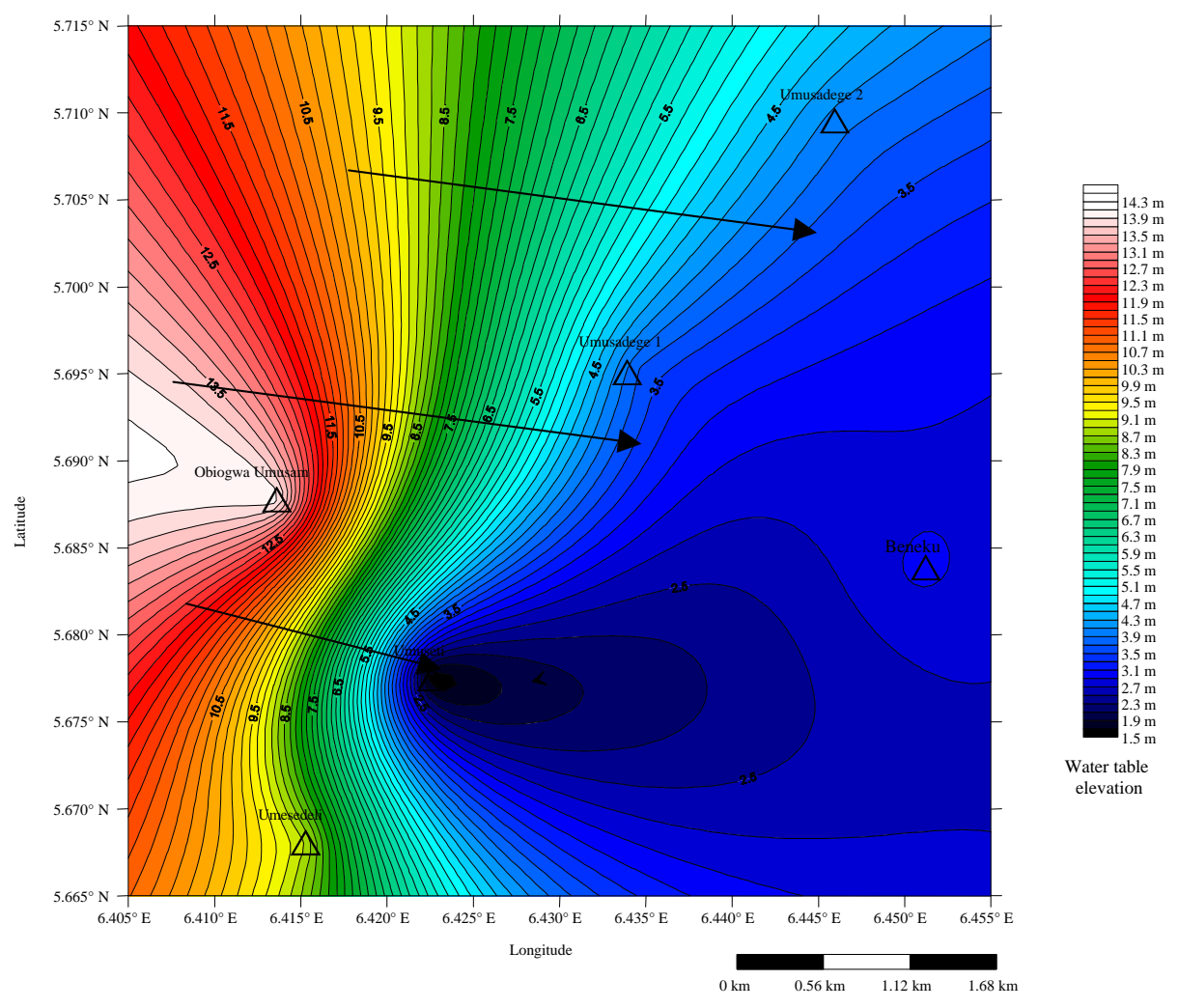

Fig. 2: Counter map of Utagba-Ogbe Kingdom showing groundwater flow direction 
contoured on the map of Utagba-Ogbe kingdom by joining equal values of static water levels and making sure that none of the lines overlapped or cut across each other. This was improved upon with the aid of surfer 8 computer package as shown in Fig. 2. The water elevation contour map of Utagba-Ogbe Kingdom revealed that groundwater flow direction is towards the Eastern part of the region.

\section{CONCLUSION}

The water elevation contour map of Utagba-Ogbe Kingdom revealed that groundwater flows towards the western part of the region.

\section{RECOMMENDATIONS}

Based on the flow pattern in the Kingdom, it is therefore recommended that dumpsites should be located within the eastern part of Utagba-Ogbe Kingdom and none in the North, South and Western regions of the land in order to minimize contamination.

The research did not only pave way for a clear picture of the flow system in Utagba-Ogbe kingdom but went further to recommend that boreholes for potable water could be sited within the North, South and Western part of kingdom.

\section{REFERENCES}

Akpokodje, E.G., 1979. The importance of engineering geological mapping in the development of the niger delta basin. Bull. Eng. Geol. Environ., 19: 101-108.

Akpokodje, E.G., 1987. The engineering geological characteristics and classification of the major superficial soils of the Niger Delta. Eng. Geol., 23: $193-211$.

Allen, J.R.L., 1965. Late quaternary Niger delta and adjacent areas: Sedimentary environments and lithofacies. Bull. Am. Pet. Geol., 49: 547-600.

Asseez, L.O., 1970. Groundwater resources of Southwestern Nigeria. Nig. Eng., 7: 22-45.
Asseez. L.O., 1976. Review of the Stratigraphy, Sedimentation and Structure of the Niger-Delta in Geology of Nigeria. Elizabethan Publishing Co., Lagos, Nigeria.

Avbovbo, A.A., 1970. Tertiary lithostratigraphy of the niger delta. Bull. Am. Assoc. Pet. Geol., 63: 295-306.

Buddemeier, R.W. and J.A. Schloss, 2000. Groundwater storage and flow. http://www.kgs.ku.edu/HighPlains/ atlas/apgengw.htm.

Burke, K.K., 1972. Long stone drift, submarine canyons and submarine fans in the development of the NigerDelta. AAPG Bull., 56: 1975-1983.

Etu-Efeotor, J.O. and E.G. Akpokodje, 1990. Aquifer systems of the Niger Delta. Nig. J. Mining Geol., 26: $279-284$.

Hospers, J., 1965. Gravity field and structure of the Nigerdelta. Nig. Geol. Soc. Am. Bull., 76: 407-422.

Kogbe, C.A. and L.O. Asseez, 1970. Geology of Nigeria, the Stratigraphy and Sedimentation of the Niger Delta. Elizabethan, Lagos, pp: 311-323.

Maron, P., 1969. Stratigraphical aspects of the Niger delta. Nig. J. Mining Geol., 4: 3-12.

Oomkens, E., 1974. Lithofacies relation in late quaternary niger-delta complex. Sedimentology, 21: 195-222.

Oseji, J.O., E.A. Atakpo and E.C. Okolie, 2005. Geoelectric investigation of the aquifer characteristics and groundwater potential in Kwale, Delta state, Nigeria. J. Applied Sci. Environ. Mgt., 9: 157-160.

Oyedele, K.F., 2001. Geoelectric investigation of ground water resources at Onibode is, near Abeokuta SouthWest, Nigeria. Global J. Pure Applied Sci., 7: 501-506.

Rement, R.A., 1965. Aspects of Geology of Nigeria. University of Ibadan Press, Ibadan, Nigeria, pp: 133.

Short, K.C. and A.J. Stauble, 1967. Outline geology of niger-delta. Am. Assoc. Pet. Geol. Bull., 51: 761-799.

Tyson, A.N., 1993. Georgia's ground water resources. US Geological Survey. Bulletin Paper No. 1096, pp: 1-11. http://www.p2pays.org/ref/37/36833.pdf.

Wilson, E.M., 1990. Engineering Hydrogeology. Macmillan Press Ltd., London, pp: 348. 